\title{
ECONOMIC SCIENCE IN UKRAINE: CHALLENGES, PROBLEMS AND WAYS OF THEIR SOLVING
}

UDC 165

\author{
๑ 2019 KYZYM M. O., DORONINA M. S.
}

JEL Classification: $B 00$

Kyzym M. O., Doronina M. S.

Economic Science in Ukraine: Challenges, Problems and Ways of their Solving

World experience shows that an effective activity of a country largely depends on the correct choice of priorities to support the development of its science, the choice of ways to finance it. Although many publications of scientists partially provide solutions to this problem, methodological and practical justification for a comprehensive study of reserves for the development of domestic economic science under current conditions of the life of society remains relevant. The aim of this article is to summarize the prerequisites for updating the theoretical and methodological support for the formation of the economic basis of Ukraine and identify some reserves for the development of this process. In the course of the research, it was found out that the sources of problems of economic science are: lack of systematization of a significant amount of available economic knowledge, which often creates problems with their practical implementation; still weak efforts on introducing the behavioral models of the economy. It is urgent to update the methodological basis for the accumulation of knowledge at all its levels: philosophical, general scientific, at the level of specific disciplines. There is no systematic procedure for diagnosing the cultural, socially reflective, humanitarian, environmental, moral functions of science. There is a need for a conceptual definition of the essence and content of fundamental and applied research, the choice of their optimal combination in solving various problems of economic theory and practice. The traditional picture of the world in studying economic problems urgently needs to be rationally supplemented with the recommendations of synergetics, capable of finding constructive technologies for establishing order from chaos. Diagnosing the truth of research results should be provided through an understandable professional, qualified expert examination, which can ensure creating a system of criteria to assess a specific subject and obtain a particular result.

Keywords: economic science, theoretical and methodological support, behavioral model of the economy, combination of fundamental and applied researches, synergetic technology, criteria for evaluating research effectiveness, examination of research results.

DOI: https://doi.org/10.32983/2222-0712-2019-3-156-163

Tabl.: 1. Bibl.: 23.

Kyzym Mykola 0. - Doctor of Sciences (Economics), Professor, Corresponding Member of NAS of Ukraine, Director of the Research Centre of Industrial Problems of Development of NAS of Ukraine (2 floor 1a Inzhenernyi Ln., Kharkiv, 61166, Ukraine)

E-mail: ndc_ipr@ukr.net

ORCID: http://orcid.org/0000-0001-8948-2656

SPIN: http://elibrary.ru/7616-1550

Doronina Maya S. - Doctor of Sciences (Economics), Professor, Senior Research Fellow of the Research Centre of Industrial Problems of Development of NAS of Ukraine (2 floor 1a Inzhenernyi Ln., Kharkiv, 61166, Ukraine)

E-mail:doroninamas@gmail.com

ORCID: https://orcid.org/0000-0001-8074-375X

Кизим М. О., Дороніна М. С. Економічна наука в Україні: виклики, проблеми, шляхи вирішення

Світовий досвід свідчить, що ефективна життєдіяльність країни багато в чому залежить від правильності вибору пріоритетів підтримки розвитку ії науки, вибору способів ії фінансування. Хоча в багатьох публікаціях учених частково наведені рішення цієї проблеми, все ще залишаються актуальними методологічні та практичні обгрунтування комплексного вивчення резервів розвитку вітчизняної економічної науки в наявних умовах життя суспільства. Метою цієї статmі $\epsilon$ узагальнення передумов поновлення теоретико-методологічного забезпечення формування економічного базису України та визначення деяких резервів розвитку цього процесу. У процесі дослідження встановлено, що джерелами виникнення проблем економічної науки є: несистематизованість значного обсягу наявних економічних знань, яка створює найчастіше проблеми втілення їх в практику; поки ще слабка робота з упровадження в практику поведінкових моделей економіки. Склалася необхідність термінового поновлення методологічного базису накопичення знань на всіх його рівнях: філософському, загальнонауковому, на рівні конкретних дисциплін. Відсутня системна процедура
Кизим Н. А., Доронина М. С. Экономическая наука в Украине: вызовы, проблемы, пути решения

Мировой опыт свидетельствует, что эффективная жизнедеятельность страны во многом зависит от правильности выбора приоритетов поддержки развития ее науки, выбора способов ее финансирования. Хотя во многих публикациях ученых частично представлены решения этой проблемы, все еще остаются актуальными методологические и практические обоснования комплексного изучения резервов развития отечественной экономической науки в сложившихся условиях жизни общества. Целью данной статьи является обобщение предпосылок обновления теоретико-методологического обеспечения формирования экономического базиса Украины и определение некоторых резервов развития этого процесса. В процессе исследования установлено, что источниками возникновения проблем экономической науки являются: несистематизированность значительного объема имеющихся экономических знаний, которая создает зачастую проблемы воплощения их в практику; пока еще слабая работа по внедрению в практику поведенческих моделей экономики. Сложилась необходимость срочного обновления методологического базиса накопления знаний на 
діагностування культурної, соціально-реслексивної, гуманітарної, екологічної, моральної функцій науки. Назріла необхідність концептуального визначення сутності та змісту фундаментальних і прикладних досліджень, вибору їх оптимального поєднання у вирішенні різних проблем економічної теорії та практики. Традиційна картина світу в дослідженнях економічних проблем терміново потребує раціонального доповнення рекомендаціями синергетики, здатної знаходити конструктивні технології становлення порядку з хаосу. Діагностику істинності результатів наукових досліджень необхідно забезпечити зрозумілою професійною, кваліфікованою експертизою, здатною створити систему оціночних критеріїв під конкретний предмет і результат.

Ключові слова: економічна наука, теоретико-методологічне забезпечення, поведінкова модель економіки, поєднання фундаментальних і прикладних досліджень, технології синергетики, оціночні критерії есрективності досліджень, експертиза результатів досліджень.

Табл.: 1. Бібл.: 23

Кизим Микола Олександрович - доктор економічних наук, професор, член-кореспондент НАН України, директор Науково-дослідного чентру індустріальних проблем розвитку НАН України (пров. Інженерний, 1a, 2 пов., Харків, 61166, Україна)

\section{E-mail:ndcipr@ukr.net}

ORCID: http://orcid.org/0000-0001-8948-2656

\section{SPIN: http://elibrary.ru/7616-1550}

Дороніна Майя Степанівна - доктор економічних наук, професор, старший науковий співробітник Науково-дослідного центру індустріальних проблем розвитку НАН України (пров. Інженерний, 1a, 2 пов., Харків, 61166, Україна)

E-mail:doroninamas@gmail.com

ORCID: https://orcid.org/0000-0001-8074-375X всех его уровнях: философском, общенаучном, на уровне конкретных дисциплин. Отсутствует системная процедура диагностирования культурной, социально-рефлексивной, гуманитарной, экологической, нравственной функций науки. Назрела необходимость концептуального определения сущности и содержания фундаментальных и прикладных исследований, выбора их оптимального сочетания в решении различных проблем экономической теории и практики. Традиционная картина мира в исследованиях экономических проблем срочно нуждается в рациональном дополнении рекомендациями синергетики, способной находить конструктивные технологии становления порядка из хаоса. Диагностику истинности результатов научных исследований необходимо обеспечить понятной профессиональной, квалифицированной экспертизой, способной создать систему оценочных критериев под конкретный предмет и результат.

Ключевые слова: экономическая наука, теоретико-методологическое обеспечение, поведенческая модель экономики, сочетание фундаментальных и прикладных исследований, технологии синергетики, оценочные критерии эффективности исследований, экспертиза результатов исследований.

Табл.: 1. Библ.: 23.

Кизим Николай Александрович - доктор экономических наук, профессор, член-корреспондент НАН Украины, директор Научно-исследовательского центра индустриальных проблем развития НАН Украины (пер. Инженерный, 1a, 2 эт., Харьков, 61166, Украина)

E-mail:ndc_ipr@ukr.net

ORCID: http://orcid.org/0000-0001-8948-2656

SPIN: http://elibrary.ru/7616-1550

Доронина Майя Степановна - доктор экономических наук, профеессор, старший научный сотрудник Научно-исследовательского чентра индустриальных проблем развития НАН Украины (пер. Инженерный, 1a, 2 эт., Харьков, 61166, Украина)

E-mail: doroninamas@gmail.com

ORCID: https://orcid.org/0000-0001-8074-375X
Introduction. Identifying sources for the restoration of the vital activity of our society is possible due to the development of science, purposeful accumulation of new knowledge. This requires, firstly, intensifying processes of cognition, accumulation of knowledge; and, secondly, aligning the existing knowledge, organizing it in a harmonious, purposeful, understandable system. In the coming years, Ukrainian economists should concentrate their efforts on examining reserves to create a socially-oriented market economy, studying in-depth transformation processes that take place in the Ukrainian economy and increasing its competitiveness.

Global practices demonstrate that an effective activity of a country largely depends on the correct choice of funding priorities and support for the development of science. For this purpose, it is advisable to build a national organizational framework of science based on combining a sectorial approach, which is focused on ensuring the general progress of scientific knowledge; and a problem-oriented one, which mostly corresponds to market relations. A sectorial approach should dominate the field of fundamental research and development and be based on the use of permanent frameworks, while a problemoriented approach should dominate the field of applied research and development, where both permanent and temporary organizational frameworks can be used.
Analysis of recent researches and publications. The material for the article are publications representing the opinion of scientists on current problems of economics M. Dovbenko [1], N. Mamontova [2], E. Balatsky [3]; ways of updating the methodological basis of science - O. Punchenko [5], V. Shkurat [6], R. Shevchuk [7], a team of Russian scientists [12]; diagnosing limitations in the development of economic science - V. Cherkasov [11], N. Polyakova [22]; updating tools for cognition of the new economic reality - O. Punchenko [5], V. Budanov [8], S. Goncharenko [9]; methods to prove the truth of research results - M. Shishkin [18], V. Horovyi [16], L. Popova [23]; conceptual and categorical framework of research - N. Kantysheva [19], V. Hrynko and S. Holubev [20], and others.

The aim of the article is to generalize the prerequisites for creating theoretical and methodological support for the formation of the economic basis of Ukraine and to identify reserves for the development of this process.

Presentation of basic material of the research. At present, the development of science, including economics, demonstrates the following regularities: transformation of science into an independent and complex cognitive and social system; continuous growth of the volume of scientific information; growth in the significance of the world view substantiation of scien- 
tific knowledge; intensification of the processes of exchanging scientific technologies and achievements of special disciplines; enhancement of the internal relationships between science and education, provision of their diversification. On the one hand, these regularities contribute to the preservation and development of the competitiveness of the economy, and on the other hand, complicate the search for reliable practical reserves for its sustainable growth.

Works of modern scientists present both generalization of problems of science and recommendations for its transformation.

For example, M. Dovbenko expresses the following ideas about sources of problems in economic science, "A significant arsenal of economic knowledge is constantly being accumulated. It is rapidly becoming more complicated, forming an extremely fragmented and unsystematized array. On the one hand, this makes it less understandable for non-specialists: the changes are systemic and they occur so fast that the process of their comprehending does not keep pace with them (sometimes the incomprehensibility, ambiguity of theoretical schemes even frightens off). On the other hand, every year, it becomes not only harder and harder for specialists to study it but, most importantly, to extract from it the practical basis, which is essential for establishing the mechanism of optimal functioning of the world economy, creating a technology for its transformation in accordance with the interests and needs of man" [1].

$\mathrm{N}$. Mamontova believes that the crisis unfolding in modern science is associated with the discrepancy between the research object and economic realities. The generally accepted paradigm is based on the principle of modeling, the application of which, in any case, results in significant errors and the appearance of anomalies, which cannot be explained from the standpoint of existing economic theories. The weak point of the modern paradigm is not false research methods but an oversimplified idea of the research object [2].

In 2006, E. Balatsky, currently the Director at the Center for Macroeconomic Research of the Financial University under the Government of the Russian Federation, published an article [3], where he presented his opinion on the problems of economic science.

Crisis of the categorial apparatus (the concepts that need to be revised are fixed and working capital, consumption and accumulation of investments, production and operation facilities, labor productivity, types of money and their functions).

Crisis of methodological imperatives (trivialization of knowledge, need to return to man, need to strengthen scientific pragmatism).

Crisis of measurement technologies (inadequacy of economic and statistical measures, contradictions between social and economic measures, crisis of scientific tests).

Aggravation of relations between economics and allied sciences (exhaustion of the "potential of discoveries", drain of economists into allied scientific disciplines).

The author concludes, "The challenges of our time to economic science are quite real and serious. It is difficult to say how they will be overcome. Quite possibly, it is within the framework of economics that the unification of the basic social sciences will go" [3].
The unique conditions of the modern stage of scientific cognition require clarifying its essence and content, updating its methodological basis. Its content is determined ambiguously in the scientific community.

For example, O. Punchenko expresses the following idea about this construct, "In fact, the methodology of science is a theory of scientific cognition, it investigates cognitive processes. In a real embodiment, it includes not only the totality of the applied methods but also other elements of the cognitive process (goals, concepts, tasks, hypotheses, etc.) associated with them; the principles of the organization of research activity - consistency, systematicity, determination, controllability, comparison of the results of cognition with its goals, cogitating over the entire structure of the study" [5].

V. Shkurat gives his own interpretation, "Methodology is defined as: a set of philosophical methods of cognition; a system of methods of cognition, in particular, special research ones; the general theory of cognition methods; a multi-level "construction", on the upper "floors" of which there placed the philosophical methodology, followed by the general scientific methodology; and on the lower ones - the methodology of sectoral researches" [6].

R. Shevchuk pays attention to the origin of the methodology and its elements. He believes, "Methodology arose and was developed as an aspect of philosophical understanding of the world, aimed at a critical understanding of philosophical and scientific cognition methods" [7]. The author considers it necessary to distinguish the following elements in the methodology of scientific cognition: ideals and norms of scientific cognition, world view, philosophical foundations of cognition [7].

E. Balatsky proposes to abandon traditional models, concepts of economic science and begin to actively study their behaviors, "Economic science, starting from a certain psychological reference point, builds a powerful theory of the functioning of the socio-economic system. However, the reference point is identified by economists not quite carefully. An error in determining this point results in errors in economic forecasts. Is it possible to change something in this situation? If we succeed to combine behavioral motives of economic participants and traditional economic "mechanics", the answer to the question is affirmative. In practice, this is very problematic, since we are talking about the development of a methodological apparatus for "translating" behavioral patterns of individuals and societies into economic and mathematical models. It seems to me that such work can become a separate, very important area of economic science" [4].

The team of Russian scientists [12] has formulated three options for determining the essence of science and its purpose, "Of multiple possible representations, we consider three manifestations of science the most important. This is, firstly, science as a special historically developed, fairly stable and, in its own way, even conservative type of thinking and activity. Secondly, this is science as an institutionalized field of activity, uniting many organizations and establishments, fully or partially engaged in scientific work. Thirdly, this is science as a combination (and, in theory, even a system) of accumulated scientific knowledge, as an essential element of culture and almost the basis of our civilization" [12]. 
The history of science in general and economic science, in particular, indicates that when its subject is changed (currently, its content is being enriched), conceptual discrepancies arise in the scientific community. This process activates changes in the style of thinking, paradigms, ideals of explanation, standards of expediency and rationality.

The analysis of publications on the problem of updating methodological guidelines of economic science proved the widespread opinion of researchers that synergetics, which can ensure a constructive combination of representations of economic practice and theory, can be considered a tool for understanding the new economic reality. Dialectics considers the system of "production forces - production relations" in economics from the standpoint of philosophy, without going deeper into their qualitative evolution, while synergetics goes deeper into studying chaos and proves its constructiveness. The synergistic paradigm has no clear, predominant line of the world development. In the new concept, reality appears as the interaction of many different developing systems that are open and far from equilibrium.

O. Punchenko states, "Synergetics as a methodological innovation includes new priorities of the general world view: concept of an unstable, nonequilibrium world, phenomenon of uncertainty and multi-alternative development, idea of establishing order from chaos. Chaos acts as a multidimensional phenomenon (simple, complex, deterministic, narrowband, large-scale, dynamic, etc.) that accompanies the irregular behavior of nonlinear media" [5].

"Synergetics," V. Budanov notes, "is born and developing at the intersection, constructive synthesis of three principles, namely: non-linear modeling, practical philosophy and subject knowledge; the intersection is especially effective in interdisciplinary interactions" [8].

The paradigm of synergetics is radically changing one of the initial principles of modern European science, which implies that a person occupies a privileged position in the world. A characteristic feature of our time is humanization of science, expectation that human creative activity will contribute, firstly, to the evolution of the biosphere and its transformation into the noosphere, and, secondly, to the satisfaction of all social, material and spiritual needs of society.

"Today, not only the world has become different - open, but, most importantly, the modern man in a new way understands, comprehends this world and his place in it. It is these changes in the man that are the most significant among all critical changes in the world and society", S. Goncharenko notes [9]. The new generation requires support in the processes of socialization, cultural identification, formation of spiritual and moral stability in the context of globalization. The point is the basis of human existence [9].

E. Balatsky has his own view on the restructuring of economics, "At present, there is so much absolutely unnecessary material in economic science that the problem is to clear it by getting rid of this "trash". Indeed, it seems that the whole immeasurable mass of publications on economics, comprising sophisticated models, theorems and calculations, is not applied in practical life. A paradoxical situation is taking shape: the most significant results can only be obtained in the field of mathematizing economics, with the latter having reached the level of complexity when it cuts off itself the vast majority of its potential consumers. In this case, a certain contradiction in the development of the science is obvious: mathematical modeling has become the main method of cognition of economic systems; a model, by definition, is a simplified reflection of reality to facilitate research; if the model becomes too complex, it loses its value as a tool of cognition". [3]. According to the author, despite the importance of these methods, they are nothing more than tools that perform an auxiliary function in economic research.

G. Plekhanov drew attention to the auxiliary function of the mathematical method in scientific research, "Mathematics cannot indicate, and does not pretend to indicate, factors of social life and nature. It only helps us determine the quantitative side of the effects of these factors" [10].

Of course, the development of economic science in Ukraine has its own limitations, which should be diagnosed and overcome. One of them is the refinement of the classification of branches of economics.

We can agree with the opinion of V. Cherkasov that classification of sciences is of great importance in the development of scientific support for the life of society. "Based on the subject and methodological connections of scientific disciplines and their groups, classification contributes to the directed movement of science from the empirical accumulation of knowledge to the level of theoretical synthesis, a systems approach to scientific problems" [11].

The most common criterion for classification of scientific knowledge is its branch structure (biology, physics, chemistry, mathematics, etc.).

Depending on the research methods, theoretical, theoretical, and experimental studies are distinguished.

Organization of scientific activity in society involves assessing its expediency. In terms of orientation and relation to practice, it is customary to divide sciences into fundamental and applied ones. In a simplified presentation of the content of this classification, a fundamental science is defined as an activity of researchers without specific commercial or other practical goals, an applied science - as an activity aimed at obtaining a specific scientific result that can be directly or potentially used to satisfy private or public needs. In the system of sciences, these two varieties are presented as a dichotomy (Tbl. 1).

The task of fundamental sciences is to understand the laws that govern the behavior and interaction of the basic structures of nature and society. Applied sciences can develop with the predominance of both theoretical and practical issues [11].

An outstanding Ukrainian researcher and educator S. Goncharenko has his own opinion on the content and purpose of domestic fundamental and applied researches, "Traditionally, the goal of a fundamental science is to obtain and theoretically systematize objective knowledge of reality. The ultimate goal of an applied science is considered to be an accurate, effective recipe for solving practical issues. The search for true knowledge acts as a self-sufficient goal for a fundamental research; while for an applied research instrumental knowledge is important, and its main value is efficiency. Naturally, applied researches are carried out based on fundamental ones" [17]. S. Goncharenko comments on the opinion of scientists who determine the priority role of fundamental research in science in this way, "Without a deeply justified progressive development 
Division of sciences into fundamental and applied ones

\begin{tabular}{|l|l|l|}
\hline \multicolumn{1}{|c|}{ Branch of science } & \multicolumn{1}{|c|}{ Fundamental } & \multicolumn{1}{c|}{ Applied } \\
\hline \multirow{2}{*}{ Biology } & Botany & Hoticulture \\
\cline { 2 - 3 } & Zoology & Animal husbandry \\
\hline \multirow{3}{*}{ Chemistry } & Inorganic chemistry & Metallurgy \\
\cline { 2 - 3 } & Organic chemistry & Plastic production \\
\hline \multirow{2}{*}{ Mathematics } & Cybernetics & Programming \\
\cline { 2 - 3 } & Theory of probability & Mathematical statistics \\
\hline
\end{tabular}

of fundamental and theoretical scientific researches, one cannot expect any significant applied scientific results. Applied researches, the emergence of innovative technologies, their productive adaptation and intersectoral integration in the field of production inevitably involve conducting a simultaneous, and, perhaps, synchronous fundamental researches" [17].

As regards economic science, Ukraine has not developed criteria for diagnosis and optimal combination of fundamental and applied research, distribution of sources and size of their funding by the National Academy of Sciences. In this context, the conclusions of a multidisciplinary research team that analyzed a large number of opinions are of interest:

1. If we want to advance towards constructing the concepts "fundamental" - F and "applied" - A, we should bear in mind that these concepts can exist only in pair and are interdependent. No occupation per se, considered regardless of its activity context, can be qualified as F or A: F is such in relation to it's $A$, and vice versa $A$ is meaningful as such in relation to its $\mathrm{F}[12]$.

2. Taking into consideration numerous examples from the history of science, it can be argued that the same scientific knowledge can be used both as fundamental and as applied [12].

3. Defining sciences of one type or another as F or A is determined by the cultural and historical situation (which, we note in brackets, may develop differently in different countries) [12].

An important point associated with the expediency of both fundamental and applied researches, in any case, is the proof of the truth of their results. M. Shishkin - Dr.Sc. (Econ.), Prof., Department of History of Economics and Economic Thought, Saint Petersburg State University believes that this problem is difficult to solve in relation to economic science. Moreover, he gives an explanation, "For exact natural disciplines, the leading criterion of truth is experience. The conditions under which a research object is observed generally remain unchanged, which makes it possible to reproduce the experiment. The situation that exists in economic science is different. The laws of economics appear as trends, conducting an experiment in most cases is impossible or extremely expensive, and here the nature of truth is rather different from the nature of truth in the natural sciences. While in the natural sciences truth is absolute, in economic analysis it is to a significant extent relative. While in the natural sciences an object is considered as a constant value, at least during the existence of mankind, in economic science it continuously changes in time. Consequently, the laws of eco- nomics, being correct for one stage of the development of society, may not function at its other stages. Society is changing, its economic basis is changing, and other objective laws start working. Therefore, the theory that was true one hundred years ago may turn out to be false now" [18].

The problem of assessing the quality of scientific researches in the context of their effectiveness was studied by V. Horovyi, who concluded that this assessment needs further analysis [16]. "The development of the advanced methods for measuring criteria of effectiveness of science is a very important matter, since it provides the opportunity to solve a quite complex for our society problem of effective administrative management of scientific activity, intended to connect the interests of society with its scientific component. Optimally, this department should provide effective scientific support for both national and public development, impeding creative search as little as possible and promoting the productive use of its results" [16].

L. Popova carried out a detailed analysis of approaches to determining effectiveness of scientific researches and concluded that it is possible to use the following criteria for its assessment: 1 . Nature of scientific work - applied, fundamental (theoretical, methodological or technical development). 2. Scientific importance of the research object (subject) for a specific scientific problem of a particular field, discipline. 3. Depth of investigation into the research object (subject). 4. Level of scientific cognition (theoretical, empirical). 5. Informational and cognitive form of scientific result (theory, law, hypothesis, model, scientific classification or systematization of certain scientific information). 6 . Breadth of coverage by the scientific result of the objects or phenomena of this (specific) area or branch of science. 7. Novelty of the scientific result compared to the well-known body of knowledge in this particular problem, area or field of research. 8. Depth of penetration of cognition into the essence of the research object (subject, phenomenon). 9. Degree of influence of the scientific result on a particular branch of science or its structural components (level of conceptual shift in this scientific field or other branches of scientific knowledge). 10. Degree of completeness and reliability of the result obtained [23].

Moreover, the author believes that the selection and development of a specific system for assessing $R \& D$, in the field of both applied and fundamental science, depends on the problems studied, structure and power of scientific and methodological centers and other specific research conditions [23].

In this regard, V. Horovyi notes, "An important issue in this case is the provision of professional, qualified expertise. 
Obviously, given the growing importance of the production of scientific information for social development, this kind of activity should be carried out collectively, reflecting the interests of the customer, qualified scientific experts, and representatives of the sphere of research management in relevant assessment structures" [16].

Despite the features of the object and method of economic research mentioned above, in the final reckoning, the criterion of truth of results is their compliance with the demands of real economic life. Domestic economic science should be modified based on this principle, using a synergistic approach to the consideration of the relationship and interaction of fundamental and applied sciences.

Gnosiology distinguishes the concepts "truth" and "knowledge". The concept "truth" means the correspondence of knowledge to reality, the reliability of its content regardless of the cognizing subject and existence independently of it due to its objectivity. The concept "knowledge" is a form of recognition of truth, which assumes the existence of certain grounds, depending on the sufficiency of which there are various forms of recognition of truth: opinion, faith, practical ordinary knowledge, scientific knowledge.

One of the important trends in the development of economic research can be considered their orientation towards using tools and technologies of related humanistic disciplines. Concerning this matter, O. Palagin and O. Kurgaev write, "Problem situations that arise on the path of the endless process of cognition are constantly becoming more complicated, each time covering more phenomena of reality, a vast majority of them requiring interdisciplinary research" [13].

Here, discussions arise primarily about clarifying the content of concepts and terms used in different scientific disciplines, and the applicability of old concepts to new phenomena. This issue is a concern for many scientists.

O. Palagin and O. Kurgaev believe that the complexity of the subject of research in economic science significantly limits the productivity of scientists due to the need to overcome barriers of interdisciplinary researches. "Any interdisciplinary research is in defining new relationships among the concepts of incoming disciplines, establishing new laws that bind them and synthesizing the pragmatics of solving new increasingly complex problems. At the same time, the knowledge of source disciplines can remain unchanged (the simplest, linear case of interdisciplinary interaction), introduced entirely (or selectively) into a new hierarchical structure, or be modified, develop due to the exchange of paradigmatic attitudes, concepts and methods of different sciences (nonlinear interdisciplinary interaction), which is a reflection of the essence of an interdisciplinary problem. Nonlinear interdisciplinary interaction together with problem orientation is a universally recognized norm in the evolution of modern science" [13].

M. Dovbenko also believes that the problem of professional and intelligible interpretation of new knowledge, its dissemination in society and, most importantly, introduction in the higher education system is becoming urgent now. Indeed, as early as in December 2003, at the theoretical and methodological seminar organized by Interagency Coordinating Council of the National Academy of Sciences of Ukraine and the Ministry of Education and Science of Ukraine on Economic Theory indicated "the inability of the existing programs, course books and study guides to reflect radical changes in the real economic life of the country" [1].

Solving the problem is possible though creating a special term system for a particular research. This procedure is described in sufficient detail and in a logical way in publications of N. Kantysheva [19], V. Hrynko and S. Holubev [20].

The development of domestic economic science needs funding, which is provided by the Academy of Sciences of Ukraine guided in this issue by regulatory documents. Public funding of a particular research is determined by its status, whether it is defined as a fundamental or applied one. However, its diagnosing, in view of the interpretation of regulatory documents, is rather complicated. The Law "On Scientific and Scientific and Technical Activity" N 848-VIII dated November 26, 2015) contains the following definitions: "Fundamental researches are theoretical and experimental researches aimed at gaining new knowledge about the laws of organization and development of nature, society, man, their interrelations. The result of fundamental researches is hypotheses, theories; new methods of cognition; discovery of laws of nature, previously unknown phenomena and properties of matter; identification of patterns of social development, etc., which are not focused on direct practical application in the field of economics. Applied researches are theoretical and experimental researches aimed at obtaining and using new knowledge for practical purposes. The result of applied scientific researches is new knowledge designed to create new or improve existing materials, products, devices, methods, systems, technologies, specific proposals for fulfilling urgent scientific, technical and social tasks".

Representatives of academia express their opinion on this matter. Academician S. Goncharenko, for example, believes that the relationship between fundamental and applied researches is determined not only by financial mercantile issues. It is important to get rid of fuzziness and inconsistency in issues of terminology and content. The need for a more or less unambiguous understanding of the essence and nature of fundamental and applied researches is becoming urgent [17]. "With a fundamental research, results are presented at the level of transformation. This level is characterized by radically new approaches that previously were not used in theory and practice, it differs radically from the well-known ideas in this field ... Applied researches, as a rule, provide results at one of two levels. The first level is that of concretization: clarification of the previously known information, concretization of certain theoretical and practical provisions relating to education; changes affecting particular issues that are not of fundamental importance for understanding the essence of the phenomenon, process. The second level is that of complementation: expansion of known theoretical principles; discovery of new aspects, facets of the problem; identification of new elements, components that were not known previously" [17].

The authors of a domestic course book on scientific researches [14] presented their vision of the differences between fundamental and applied researches. In their opinion, fundamental researches are experimental or theoretical researches aimed at obtaining radically new knowledge about the laws of development of nature, society, man, their relationship. The need for this type of researches is determined by the needs of the national economy or industry. They can result in recommendations for carrying out applied researches to determine 
possibilities for the practical use of the acquired scientific knowledge, scientific publications, etc.

Applied researches are a scientific and technical activity aimed at obtaining and using knowledge for practical purposes, searching for the most rational ways of the practical use of $\mathrm{s}$ of fundamental researches in the national economy. They result in recommendations for the creation of technical innovations (innovations). Currently, almost every enlarged branch of science combines fundamental and applied sciences [14].

There is another area that requires a clear distinction between fundamental and applied researches. This is the formation of the methodology for preparing dissertation works.

The team of domestic authors offers the following positioning of the methodology in these works. In candidate's dissertations, the research methodology should be considered in the first theoretical section. In doctoral dissertations, the first section should present theoretical provisions, the subsequent section should deal with the methodology, to comprehensively determine its content in the context of the research topic [21].

In any case, applicants for a scientific degree, in their dissertations, need to demonstrate knowledge of the subject, breadth of their scientific vision, mastery in using scientific methods, objectivity, criticality, i.e, features that primarily determine professionalism of a scientist. At the same time, an important professional quality in the field of science is the level of methodological competence of the applicant, his/her knowledge and use of scientific criteria.

The argumentation of the results of researches, carried out both under the state program and within dissertations, is enhanced by a clear formulation of the system of its conceptual constructs: a new idea; hypotheses describing the areas for the search for new scientific result; the term system; principles and methods of studying and transforming the critical element of the subject area; technology of its qualitative and quantitative analysis and other aspects and research tools relevant to a particular topic.

Conclusion. In general, based on the above materials, we can draw the following conclusions. A country's activity depends on the choice of priorities for supporting the development of its scientific sector. Ensuring a successful choice depends on the quality of the methodological and practical justification for studying reserves for the development of domestic economic science. The lack of systematization of a significant amount of available economic knowledge creates problems with its practical implementation. It is urgent to update the methodological basis for accumulating knowledge at the philosophical, general scientific level, and at the level of individual disciplines. There is a need for a conceptual definition of the essence and content of fundamental and applied research, looking for their optimal combination in investigating problems in economic practice. Supplementing the traditional worldview in economic studies with recommendations of synergetics will allow to find constructive technologies for overcoming crisis situations, the intensity of which is growing. The objectivity of diagnosing research results can be ensured by understandable professional, qualified expertise.

\section{LITERATURE}

1. Довбенко М. Сучасна економічна теорія: криза чи розвиток? Вісник Національної академії наук України. 2008. № 12. C. 60-71.

2. Мамонтова Н. А. Криза сучасної економічної парадигми у формуванні інноваційного розвитку. Наукові записки [Haціонального університету «Острозька академія»]. Серія «Економіка». 2013. Вип. 23. С. 74-77.

3. Балацкий Е. В. Экономическая наука: новые вызовы современности. Мировая экономика и международные отношения. 2006. № 1. С. 61-67.

4. Балацкий Е. В. Антропогенный фактор «регресса» экономической науки. Науковедение. 2003. № 4. С. 141-163.

5. Пунченко О. П. Методологічні новації у сучасному науковому пізнанні. Гуманітарний вісник Запорізької державної інженерної академії. 2014. Вип. 57. С. 27-37.

6. Шкурат В. І. Методологічні підходи до аналізу особливостей державного управління в умовах глобалізації. Державне управління. 2006. № 1. С. 14-22.

7. Шевчук Р. М. Методологія наукового пізнання: від явища до сутності. Філософські та методологічні проблеми права. 2016. № 1. C. 31-45.

8. Буданов В. П. Методология и синергетика в постнеклассической науке и в образовании. М. : Либраком, 2009. 240 с.

9. Гончаренко С. У. Про фундаментальні і прикладні педагогічні дослідження. Професійна освіта: педагогіка і психологія. 2010. Вип. 12. С. 113-124.

10. Плеханов Г. В. Избранные философские произведения : в 5 т. М. : Госполитиздат, 1956. Т. 2. 823 с.

11. Черкасов В. Ф. Етапи розвитку науки і класифікація наукових знань. Збірник наукових праць [Херсонського державного університету]. Серія «Педагогічні науки». 2017. Вип. 78. Том 1. С. 56-60.

12. Коршунова Н. Л., Котельников С. И., Литвинов В. П., Матьяш О. И., Рац М. В. Понятия фундаментального и прикладного и их приложение в науке // Альманах «Наука. Инновации. Образование». 2013. № 14. Языки славянской культуры. C. 67-80.

13. Палагін О., Кургаєв О. Міждисциплінарні наукові дослідження: оптимізація системно-інформаційної підтримки. Вiсник Національної академії наук України. 2009. № 3. С. 14-25.

14. Марцин В. С., Міценко Н. Г., Даниленко О. А. та ін. Основи наукових досліджень : навч. посіб. Львів : Ромус-Поліграф, 2002. 128 c.

15. Андрійчук В. Г. Сутнісний аспект методології наукових досліджень. Економіка АПК. 2016. № 7. С. 87-94.

16. Горовий В. М. Критерії якості наукових досліджень у контексті забезпечення національних інтересів. Вісник Національної академії наук України. 2015. № 6. С. 74-80.

17. Гончаренко С. У. Про фундаментальні і прикладні педагогічні дослідження, або «Не споруджують освіту на піску». Шлях освіти. 2010. № 2. С. 2-10.

18. Шишкин М. В. Методология экономического анализа и верификация теории: основные тенденции развития. Becmник Санкт-Петербургского университета. Сер. 5. Экономика. 2007. № 2. C. 22-28.

19. Кантышева Н. Г. Концептуальное моделирование междисциплинарных терминосистем. Вестник Челябинского государственного университета. 2013. № 29. Филология. Искусствоведение. Вып. 83. С. 73-76.

20. Гринько В. Г., Голубєв С. М. Технологія розробки терміносистеми дослідження ресурсів інтелектуального капіталу 
підприємства. Культура народів Причорномор'я. 2011. № 195. C. 46-49.

21. Міщенко І. А., Чорний Г. М., Фіщук Н. Ю. Методологія дослідження в контексті дисертаційних і дипломних робіт з економіки. Економіка АПК. 2017. № 1. С. 87-91.

22. Полякова Н. Б. История и философия науки. Часть 1. Общие проблемы философии науки : учеб. пособие для организации самостоятельной работы аспирантов и соискателей. Ижевск : Удмурт. ун-т, 2018. 244 с

23. Попова Л. А. Оценка эффективности научно-исследовательских и опытно-конструкторских разработок (обзор литературы). Гений ортопедии. 1997. № 2. С. 93-102.

\section{REFERENCES}

Andriichuk, V. H. "Sutnisnyi aspekt metodolohii naukovykh doslidzhen" [The essential aspect of the methodology of scientific research]. Ekonomika APK, no. 7 (2016): 87-94.

Balatskiy, Ye. V. "Antropogennyy faktor «regressa» ekonomicheskoy nauki" [Anthropogenic factor of «regression» of economic science]. Naukovedeniye, no. 4 (2003): 141-163.

Balatskiy, Ye. V. "Ekonomicheskaya nauka: novyye vyzovy sovremennosti" [Economic science: new challenges of our time]. Mirovaya ekonomika i mezhdunarodnyye otnosheniya, no. 1 (2006): 61-67.

Budanov, V. P. Metodologiya i sinergetika v postneklassicheskoy nauke i v obrazovanii [Methodology and synergetics in post-non-classical science and in education]. Moscow: Librakom, 2009.

Cherkasov, V. F. "Etapy rozvytku nauky i klasyfikatsiia naukovykh znan" [Stages of science development and classification of scientific knowledge]. Zbirnyk naukovykh prats [Khersonskoho derzhavnoho universytetu]. Ser. "Pedahohichni nauky», vol. 1, no. 78 (2017): 56-60.

Dovbenko, M. "Suchasna ekonomichna teoriia: kryza chy rozvytok?" [Modern economic theory: crisis or development?]. Visnyk Natsionalnoi akademii nauk Ukrainy, no. 12 (2008): 60-71.

Honcharenko, S. U. "Pro fundamentalni i prykladni pedahohichni doslidzhennia" [About basic and applied pedagogical researches]. Profesiina osvita: pedahohika i psykholohiia, no. 12 (2010): 113-124.

Honcharenko, S. U. "Pro fundamentalni i prykladni pedahohichni doslidzhennia, abo "Ne sporudzhuiut osvitu na pisku»" [About basic and applied pedagogical studies, or «Do not construct education in the sand»]. Shliakh osvity, no. 2 (2010): 2-10.

Horovyi, V. M. "Kryterii yakosti naukovykh doslidzhen u konteksti zabezpechennia natsionalnykh interesiv" [Criteria for the quality of research in the context of national interests]. Visnyk Natsionalnoi akademii nauk Ukrainy, no. 6 (2015): 74-80.

Hrynko, V. H., and Holubiev, S. M. "Tekhnolohiia rozrobky terminosystemy doslidzhennia resursiv intelektualnoho kapitalu pidpryiemstva" [Technology of development of the term system of research of resources of intellectual capital of the enterprise]. Kultura narodiv Prychornomoria, no. 195 (2011): 46-49.

Kantysheva, N. G. "Kontseptualnoye modelirovaniye mezhdistsiplinarnykh terminosistem" [Conceptual modeling of interdis- ciplinary terminological systems]. Vestnik Chelyabinskogo gosudarstvennogo universiteta, no. 29 - Filologiya. Iskusstvovedeniye, issue 83 (2013): 73-76.

Korshunova, N. L. et al. "Ponyatiya fundamentalnogo i prikladnogo i ikh prilozheniye v nauke" [The concepts of fundamental and applied and their application in science]. Nauka. Innovatsii. Obrazovaniye, no. 14. Yazyki slavyanskoy kultury (2013): 67-80.

Mamontova, N. A. "Kryza suchasnoi ekonomichnoi paradyhmy u formuvanni innovatsiinoho rozvytku" [Crisis of the modern economic paradigm in the formation of innovative development]. Naukovi zapysky [Natsionalnoho universytetu «Ostrozka akademiia»]. Seriia «Ekonomika», no. 23 (2013): 74-77.

Martsyn, V. S. et al. Osnovy naukovykh doslidzhen [Basics of the scientific research]. Lviv: Romus-Polihraf, 2002.

Mishchenko, I. A., Chornyi, H. M., and Fishchuk, N. Yu. "Metodolohiia doslidzhennia v konteksti dysertatsiinykh i dyplomnykh robit z ekonomiky" [Research methodology in the context of dissertation and diploma thesis in economics]. Ekonomika APK, no. 1 (2017): 87-91.

Palahin, O., and Kurhaiev, O. "Mizhdystsyplinarni naukovi doslidzhennia: optymizatsiia systemno-informatsiinoi pidtrymky" [Interdisciplinary research: optimization of system-information support]. Visnyk Natsionalnoi akademii nauk Ukrainy, no. 3 (2009): 14-25.

Plekhanov, G. V. Izbrannyye filosofskiye proizvedeniya [Selected philosophical works], vol. 2. Moscow: Gospolitizdat, 1956.

Polyakova, N. B. Istoriya i filosofiya nauki. Chast 1. Obshchiye problemy filosofii nauki [History and philosophy of science. Part 1. General problems of the philosophy of science]. Izhevsk: Udmurt. un-t, 2018.

Popova, L. A. "Otsenka effektivnosti nauchno-issledovatelskikh i opytno-konstruktorskikh razrabotok (obzor literatury)" [Evaluation of the effectiveness of research and development (literature review)]. Geniy ortopedii, no. 2 (1997): 93-102.

Punchenko, O. P. "Metodolohichni novatsii u suchasnomu naukovomu piznanni" [Methodological innovations in modern scientific knowledge]. Humanitarnyi visnyk Zaporizkoi derzhavnoi inzhenernoi akademii, no. 57 (2014): 27-37.

Shevchuk, R. M. "Metodolohiia naukovoho piznannia: vid yavyshcha do sutnosti" [Methodology of scientific knowledge: from phenomenon to essence]. Filosofski ta metodolohichni problemy prava, no. 1 (2016): 31-45.

Shishkin, M. V. "Metodologiya ekonomicheskogo analiza i verifikatsiya teorii: osnovnyye tendentsii razvitiya" [The methodology of economic analysis and verification of the theory: the main development trends]. Vestnik Sankt-Peterburgskogo universiteta. Ser. 5. Ekonomika, no. 2 (2007): 22-28

Shkurat, V. I. "Metodolohichni pidkhody do analizu osoblyvostei derzhavnoho upravlinnia v umovakh hlobalizatsii" [Methodological approaches to the analysis of features of public administration in the conditions of globalization]. Derzhavne upravlinnia, no. 1 (2006): 14-22.

Стаття надійшла до редакції 05.08.2019 